\title{
Bactericidal activity of metronidazole against Bacteroides fragilis
}

\author{
J. P. F. WHELAN AND J. H. HALE
}

From the Research Laboratories, May and Baker Ltd, Dagenham, and the Public Health Laboratory, Newcastle-upon-Tyne

SYNOPSIS Metronidazole was found to be active against Bacteroides fragilis strains isolated from human lesions. The minimal inhibitory concentrations (MIC) were from 0.16 to $2.5 \mu \mathrm{g} / \mathrm{ml}$ and the minimal bactericidal concentrations (MBC) were from $0 \cdot 16$ to $2 \cdot 5 \mu \mathrm{g} / \mathrm{ml}$; usually the MIC and MBC figures were equivalent. These levels are easily attainable in the serum following normal therapeutic doses. The drug is not toxic and side effects are rare and it would therefore seem highly suitable for treating Bacteroides infections and also may be considered prophylactically in certain situations that are described.

Organisms of Bacteroides species and particularly Bact. fragilis have been incriminated in a large number of infections. They are frequently observed in sepsis following gastrointestinal surgery (Gillespie and Guy, 1956), in puerperal sepsis (Rotheram and Schick, 1969), lung abscess (Tillotson and Lerner, 1968), and brain abscess (Ingham, Selkon, Codd, and Hale, 1970). Lincomycin has been shown to possess bactericidal activity in vitro against Bacteroides species (Ingham, Selkon, Codd, and Hale, 1968; Nastro and Finegold, 1972) and Tracey, Gordon, Moran, Love, and McKenzie (1972) described four cases of Bacteroides infection successfully treated with lincomycin.

The drug metronidazole has been shown to be bactericidal in vitro against Bacteroides fragilis by Nastro and Finegold (1972). We present here the results of testing metronidazole against 23 strains isolated from clinical conditions in Britain.

\section{Materials and Methods}

Twenty-three strains of Bacteroides fragilis were obtained which had been isolated from a variety of lesions. They were maintained in cooked meat medium and on $10 \%$ blood agar under anaerobic conditions.

ANTIBACTERIAL ACTIVITY in vitro

The minimal inhibitory concentration (MIC) of

Received for publication 10 April 1973. metronidazole was determined using two-fold serial dilution in $10 \%$ blood agar incorporating the drug in the medium at a starting concentration of 50 $\mu \mathrm{g} / \mathrm{ml}$ with the first isolates and at $10 \mu \mathrm{g} / \mathrm{ml}$ in the later estimations. A 48-hour culture grown on $10 \%$ blood agar under anaerobic conditions at $37^{\circ} \mathrm{C}$ was used to inoculate the drug-containing blood agar plates. The latter were incubated overnight at $37^{\circ} \mathrm{C}$ in an anaerobic jar under $90 \%$ hydrogen and $10 \%$ carbon dioxide. The MIC values were recorded after 24 hours' incubation and the minimum bactericidal concentrations (MBC) were determined by the replica plate method of Elek and Hilson (1954) using $10 \%$ blood agar plates. The recovery plates were incubated overnight under anaerobic conditions. The criterion for bactericidal effect was that there should be no colonies on the corresponding replica plates.

\section{PATHOGENICITY EXPERIMENTS}

Attempts to produce lesions in animals were made. Two slopes of horse blood agar were inoculated with each strain, incubated for 48 hours, and the organisms on each slope washed off with $1.0 \mathrm{ml}$ of saline. This suspension was injected in $0.03 \mathrm{ml}$ amounts intracerebrally into $20 \mathrm{~g}$ albino mice. The remainder of the saline suspension was diluted with $5 \%$ hog mucin and injected intraperitoneally in $0.5 \mathrm{ml}$ volumes into $20 \mathrm{~g}$ mice. Similar slopes were inoculated and harvested and $0.5 \mathrm{ml}$ volumes of the suspension injected subcutaneously into $150 \mathrm{~g}$ guinea pigs and into $1.5 \mathrm{~kg}$ rabbits. 


\section{Results}

The minimal inhibitory and minimal bactericidal concentrations of metronidazole against 23 strains of Bacteroides fragilis are shown in the table. In all but one case the MIC and MBC figures were equivalent. One strain provided an MIC of $1.2 \mu \mathrm{g} / \mathrm{ml}$ and a MBC of $2.5 \mu \mathrm{g} / \mathrm{ml}$. The highest MIC or MBC was $2 \cdot 5 \mu \mathrm{g} / \mathrm{ml}$.

Experiments designed to demonstrate the activity of metronidazole against Bacteroides in vivo failed as all attempts to produce infective lesions by any route in any of the species employed were in vain, although pathogenicity for the guinea pig and the rabbit is described (Wilson and Miles, 1964).

\begin{tabular}{|c|c|c|c|}
\hline Strain No. & Clinical Source & $\begin{array}{l}M I C \\
(\mu g / m l)\end{array}$ & $\begin{array}{l}M B C \\
(\mu g / m l)\end{array}$ \\
\hline 17 & Blood culture & 0.7 & 0.7 \\
\hline 18 & Brain abscess & 0.7 & 0.7 \\
\hline 21 & $\begin{array}{l}\text { Peritoneal swab perforated } \\
\text { appendix }\end{array}$ & $0 \cdot 7$ & $0 \cdot 7$ \\
\hline 26 & High vaginal swab & 0.7 & $0 \cdot 7$ \\
\hline 28 & Peritonitis & $0 \cdot 16$ & $0 \cdot 16$ \\
\hline 37 & Blood culture & 0.7 & $0 \cdot 7$ \\
\hline 41 & Appendix abscess & 0.7 & $0 \cdot 7$ \\
\hline 43 & Appendix abscess & $0 \cdot 7$ & $0 \cdot 7$ \\
\hline 50682 & $\begin{array}{l}\text { Blood culture postpartum } \\
\text { pyrexia }\end{array}$ & 0.6 & 0.6 \\
\hline 51747 & $\begin{array}{l}\text { Peritoneal swab perforated } \\
\text { appendix }\end{array}$ & 0.6 & 0.6 \\
\hline 52227 & Urine, after ureteroplasty & $0 \cdot 6$ & $0 \cdot 6$ \\
\hline 52419 & $\begin{array}{l}\text { High vaginal swab, carcinoma } \\
\text { uterus c pyometrium }\end{array}$ & $1 \cdot 2$ & $1 \cdot 2$ \\
\hline 54740 & $\begin{array}{l}\text { High vaginal swab puerperal } \\
\text { pyrexia }\end{array}$ & $1 \cdot 2$ & $1 \cdot 2$ \\
\hline 55506 & $\begin{array}{l}\text { High vaginal swab vaginal } \\
\text { discharge }\end{array}$ & $0 \cdot 3$ & $0 \cdot 3$ \\
\hline 55721 & Bladder washings & $1 \cdot 2$ & $1 \cdot 2$ \\
\hline 56515 & Abdominal wound & $1 \cdot 2$ & $1 \cdot 2$ \\
\hline 56728 & Episiotomy wound & $1 \cdot 2$ & $2 \cdot 5$ \\
\hline 57292 & Peritoneal dialysis effluent & 0.6 & 0.6 \\
\hline 58914 & Appendix abscess & $1 \cdot 2$ & $1 \cdot 2$ \\
\hline 58966 & Abdominal wound & 0.6 & 0.6 \\
\hline 2787 (1) & Appendix wound & $0 \cdot 3$ & $0 \cdot 3$ \\
\hline $2787(2)$ & Appendix wound & $2 \cdot 5$ & $2 \cdot 5$ \\
\hline 3060 & Appendix wound & $1 \cdot 25$ & $1 \cdot 25$ \\
\hline
\end{tabular}

Table Minimal inhibitory concentrations $(M I C)$ and minimal bactericidal concentrations $(M B C)$ of metronidazole against 23 strains of Bacteroides fragilis isolated from clinical material ${ }^{1}$

'Estimations performed on $10 \%$ horse blood agar.

\section{Discussion}

Metronidazole has been shown to be active against parasites and bacteria which exhibit mainly an anaerobic metabolism. Thus, its activity against Trichomonas vaginalis (Durel, Roiron, Siboulet, and Bonel, 1960) and Entamoeba histolytica (Powell, Macleod, Wilmot, and Elsdon-Dew, 1966) has made it the most effective therapy in the treatment of infection with these parasites. Its activity against the organisms associated with acute ulcerative gingivitis (Vincent's disease) has secured it a position in the treatment of this condition (Shinn, Squires, and McFadzean, 1965). The effectiveness of metronidazole against Clostridia and its value in the prevention of experimental infections in mice with $\mathrm{Cl}$. tetani and $\mathrm{Cl}$. welchii were shown by Freeman, McFadzean, and Whelan (1968). Füzi and Csukás (1970) showed activity by metronidazole against the anaerobic bacteria, Fusobacteria, Bacteroides, Leptotrichia, Clostridia, and Veillonella, and suggested that the pronounced efficacy of the drug offered new possibilities in the therapy of infections i due to anaerobes. Nastro and Finegold (1972) or showed that, of five antimicrobial agents-rifampin, $\omega$ 7-chlorolincomycin, vancomycin, tetracycline, and $\stackrel{\omega}{\omega}$ metronidazole-only metronidazole had complete 음 and consistent bactericidal activity at concentrations easily attainable in serum. It has been shown (Kane, $\subseteq$

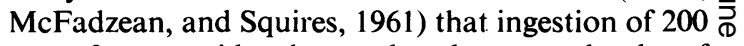
$\mathrm{mg}$ of metronidazole produced serum levels of $\vec{\varphi}$ about $5.0 \mu \mathrm{g} / \mathrm{ml}$ at one to two hours later and that the levels fell gradually to $1.0 \mu \mathrm{g} / \mathrm{ml}$ at 24 hours. Further records (Squires, 1973) indicate that patients receiving $400 \mathrm{mg}$ attain a level of $9 \mu \mathrm{g} / \mathrm{ml}$ and that serum concentrations rise progressively with increased dosage of this non-toxic compound. A single $\stackrel{2}{\circ}$

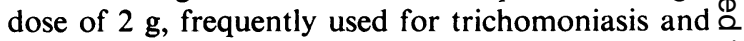
amoebiasis, will produce a serum level of $46 \mu \mathrm{g} / \mathrm{ml}, \overrightarrow{\overrightarrow{0}}$ which at 24 hours will have receded to $13 \mu \mathrm{g} / \mathrm{ml} 3$ and at 48 hours to $3.0 \mu \mathrm{g} / \mathrm{ml}$.

Information on the development of resistance to metronidazole is limited largely to observations with Trichomonads which have shown no development: of resistance to the drug in spite of wide use in the 3 . past 10 years (McFadzean, Pugh, Squires, and Whelan, 1969; Keighley, 1971; Benazet and $\frac{0}{3}$ Guillaume, 1971). Habituation of Clostridia to metronidazole was attempted over 10 passages by Freeman (1968) with no increase in inhibitory $\frac{\text { ? }}{2}$ concentration.

Tetracycline has been considered as suitable ${ }^{N}$ treatment in Bacteroides infections but Nastro and $\mathrm{N}$ Finegold (1972), Keusch and O'Connell (1966), and $\mathcal{N}$ Kislak (1972) have demonstrated resistance to $\omega$ tetracycline in this species. Lincomycin and clindamycin (Ingham et al, 1968) are regarded as treat-o ments of choice but Nastro and Finegold (1972), using zero colonies as the endpoint, showed that + 7-chlorolincomycin provided bactericidal activity against only one or two strains.

The use of an association of penicillin $G$ and $\stackrel{\mathcal{Q}}{\mathscr{P}}$ tetracycline has been suggested for the prevention of $\stackrel{\mathbb{Q}}{\circ}$ postoperative infection in certain types of case (Todd, 1968). For appendicectomy complicated by $\Omega$ 
peritonitis, or surgery involving transection of the gastrointestinal tract, we feel that ampicillin and metronidazole may prove a better combination. The latter is active against Bacteroides, an important cause of infection in such patients; it is virtually non-toxic and does not have the side effects that may be associated with tetracycline, especially in young children. Further we have shown (although not yet published) that metronidazole materially lowers the $\mathrm{Cl}$. welchii content of the colon.

\section{References}

Benazet, F., and Guillaume, L. (1971). Induction of in vivo resistance of Trichomonas vaginalis to nitrimidazine. Lancet, 2, 982-983.

Durel, P., Roiron, V., Siboulet, A., and Borel, L. J. (1960). Systemic treatment of human trichomoniasis with a derivative of nitro-imidazole, 8823 RP. Brit. J. vener. Dis., 36, 21-26.

Elek, S. D., and Hilson, G. R. F. (1954). Combined agar diffusion and replica plating techniques in the study of antibacterial substances. J. clin. Path., 7, 37-44.

Freeman, W. A. (1968). Personal communication.

Freeman, W. A., McFadzean, J. A., and Whelan, J. P. F. (1968). Activity of metronidazole against experimental tetanus and gas gangrene. J. appl. Bact., 31, 443-447.

Füzi, M., and Csukás, Z. (1970). Das antibakterielle Wirkungsspektrum des Metronidazols. Z. Bakt., I. Abt. Orig., 213, 258-262.

Gillespie, W. A., and Guy, J. (1956). Bacteroides in intra-abdominal sepsis: their sensitivity to antibiotics. Lancet, 1, 1039-1042.

Ingham, H. R., Selkon, J. B., Codd, A. A., and Hale, J. H. (1968). A study in vitro of the sensitivity to antibiotics of Bacteroides fragilis. J. clin. Path., 21, 432-436.

Ingham, H. R., Selkon, J. B., Codd, A. A., and Hale, J. H. (1970). The effect of carbon dioxide on the sensitivity of Bacteroides fragilis to certin antibiotics in vitro. J. clin. Path., 23, 254-258.
Kane, P. O., McFadzean, J. A., and Squires, S. (1961). Absorption and excretion of metronidazole. Part 1. Serum concentration and urinary excretion after oral administration. Brit. J. vener. Dis., 37, 273-275.

Keighley, E. E. (1971). Trichomoniasis in a closed community: efficacy of metronidazole. Brit. med. J., 1, 207-209.

Keusch, G. T., and O'Connell, C. J. (1966). The susceptibility of bacteroides to the penicillins and cephalothin. Amer. J. med. Sci., 251, 428-432.

Kislak, J. W. (1972). The susceptibility of Bacteroides fragilis to 24 antibiotics. J. infect. Dis., 125, 295-299.

McFadzean, J. A., Pugh, I. M., Squires, S., and Whelan, J. P. F. (1969). Further observations on strain sensitivity of Trichomonas vaginalis to metronidazole. Brit. J. ven Dis., 45, 161162.

Nastro, L. J., and Finegold, S. M. (1972). Bactericidal activity of five antimicrobial agents against Bacteroides fragilis. J. infect. Dis., 126, 104-107.

Powell, S. J., Macleod, I., Wilmot, A. J., and Elsdon-Dew, R. (1966). Metronidazole in amoebic dysentery and amoebic liver abscess. Lancet, 2, 1329-1331.

Rotheram, E. B., Jr., and Schick, S. F. (1969). Nonclostridial anaerobic bacteria in septic abortion. Amer. J. Med., 46, 80-89.

Shinn, D. L. S., Squires, S., and McFadzean, J. A. (1965). The treatment of Vincent's Disease with metronidazole. Dent. Pract., 15, 275-280.

Squires, S. (1973). In preparation.

Tillotson, J. R., and Lerner, A. M. (1968). Bacteroides pneumonias. Characteristics of cases with empyema. Ann. intern. Med., 68 308-317.

Todd, J. C. (1968). Wound infection: etiology, prevention and management including selection of antibiotics. Surg. Clin. N. Amer., 48, 787-798.

Tracey, O., Gordon, A. M., Moran, F., Love, W. C., and McKenzie, P. (1972). Lincomycins in the treatment of Bacteroides infections. Brit. med. J., 1, 280-282.

Wilson, G. S., and Miles, A. A., Eds. (1964). In Topley and Wilson's Principles of Bacteriology and Immunity, 5th ed. Arnold, London. 